\title{
How to do things with epigenetics: An investigation into the use of metaphors to promote alternative approaches to health and social science, and their implications for interdisciplinary collaboration
}

\author{
Brigitte Nerlich \\ University of Nottingham, UK
}

\author{
Aleksandra Stelmach \\ University of Exeter, UK \\ Catherine Ennis \\ University of British Columbia and BC Children's Hospital Research Institute, Canada
}

\begin{abstract}
Epigenetics is a multifaceted field within genetics and genomics which focuses on discovering mechanisms involved in gene expression and regulation. It came to public attention around the turn of the millennium when the human genome began to be deciphered. Initial findings from epigenetics research held the promise of changing how we think about health and illness, evolution and heredity; speculations about how individuals and populations could begin to control such processes through epigenetics were then picked up in the public realm. In this article we concentrate on two normally distant domains within the public sphere: the advertising of alternative health products and services, and the promotion of alternative approaches to social science, especially around how social science deals with the 'biosocial'. Using insights from social representations theory and methods aligned with metaphor analysis, we investigate the meanings of epigenetics rooted in the use of metaphors and commonplaces that are circulating in current popular parlance and that are used to promote academic theories and ideas as well as tangible products and services. We compare and contrast them and assess their implications for collaborations between natural and social scientists. Our findings reveal some surprising similarities between the metaphors and commonplaces used by advertisers and social scientists, based in large part on the fact that both groups draw on the work of prominent epigeneticists. In both instances some fundamental tenets of mainstream biology are contested, and hopes are created for improving individual or population well-being through the manipulation of epigenetic mechanisms. Both domains share some misunderstandings of epigenetics that might lead to problems with interdisciplinary collaborations between social and natural scientists.
\end{abstract}

\section{Keywords}

alternative health advertising, biosocial, epigenetic hype, epigenetic inheritance, epigenetics, metaphors, social representations, transgenerational, Twitter

\section{Résumé}

L'épigénétique est un champ de la recherche génétique et génomique aux multiples facettes s'intéressant à la découverte des mécanismes impliqués dans l'expression et la régulation des gènes. II a été porté à la connaissance du public au tournant du millénaire lorsque le génome humain a commencé à être déchiffré. Les découvertes initiales en épigénétique promettaient de changer la façon dont nous réfléchissons à la santé et à la 
maladie, à l'évolution et à l'hérédité ; des spéculations ont ensuite circulées dans le domaine public sur la manière dont les individus et les populations pourraient commencer à contrôler de tels processus par une maîtrise de l'épigénétique. Dans cet article, nous nous concentrons sur deux domaines habituellement distincts dans la sphère publique: la promotion publicitaire de produits et de services de santé alternatifs, et la promotion d'approches alternatives au traitement du " biosocial » en sciences sociales. Utilisant la théorie des représentations sociales et des méthodes alignées sur celles de l'analyse métaphorique, nous avons étudié les significations qui circulent communément au sujet de l'épigénétique, qui sont ancrées dans l'utilisation de métaphores et de lieux communs et qui sont utilisés pour promouvoir des théories et des idées académiques, tout autant que des produits et des services concrets. Nous comparons et exposons leurs différences, et nous estimons leurs conséquences pour la collaboration entre des scientifiques en sciences naturelles et des scientifiques en sciences sociales. Nos résultats révèlent des similarités surprenantes entre les métaphores et les lieux communs utilisés par les publicitaires et les chercheurs en sciences sociales, en grande partie notamment parce que ces deux groupes puisent dans le travail de chercheurs de premier plan en épigénétique. Dans les deux cas, quelques principes fondamentaux de la biologie communément admis par l'opinion publique sont remis en question, en même temps qu'est nourri l'espoir d'améliorer le bienêtre des individus et des populations à travers la manipulation des mécanismes épigénétiques. Par ailleurs, II existe plusieurs malentendus relatifs à l'épigénétique que partagent le domaine des sciences sociales et celui de la publicité et qui peuvent rendre problématiques les collaborations interdisciplinaires entre les chercheurs en sciences sociales et les chercheurs en science naturelle.

\section{Mots-clés}

battage publicitaire de l'épigénétique, biosocial, épigénétique, héritage épigénétique, métaphores, promotion publicitaire d'une médecine alternative, représentations sociales, transgénérationnel, Twitter

'[L'épigénétique] est une discipline en plein boom depuis le début des années 2000 et qui fait couler beaucoup d'encre de par les espoirs, mais aussi les fantasmes, qu'elle suscite.'

'This is a discipline that has been booming since the early 2000s and the hopes, or even fantasies, it arouses have been the subject of extensive coverage.' (Interview with Edith Heard, Cailloce, 2019)

\section{Introduction}

Epigenetics, in its modern definition, refers 'to a layer of information that exists beyond that encoded in the DNA sequence, thereby making the genome function distinctively in different cell types' (Greally, 2018). Some have put it more succinctly: epigenetics is a 'fancy word for 'gene regulation'" (Cobb, 2018).

After the completion of the Human Genome Project in 2003, other projects were launched, such as the Human Epigenome Project. Since then, various incarnations of epigenetics have attracted the attention of the media, of advertisers for a range of 
alternative health products and services (including nutritional supplements, dietary and exercise/lifestyle advice, and cosmetics), and also of academic social science commentators. While some scholars have studied media coverage of epigenetics (Stelmach \& Nerlich, 2015; Lappé, 2016), no research has analysed how epigenetics has been used in two seemingly unrelated domains of public life: in advertising and in academia, that is, in some fields of social science.

In both advertising and academia, people have not only asked what epigenetics is; they have also appropriated epigenetics to do certain things: advertisers use it to sell products, while some social scientists use it to promote a new approach to research. This promotional work often relies on the use of 'promotional metaphors' (Nelkin, 1994), exaggerated metaphorical framings that draw on existing cultural scripts to legitimate and popularise research and to create favourable representations of science (see Van Dijk, 1998).

Epigenetics seems to answer questions that were left open after the Human Genome Project and has become 'the new all-round biological explanation for everything where classical genetics can't go, including the inter-generational transmission of acquired traits, environmental impacts and complex diseases' (Häfner \& Lund, 2016: 166). In this context, some natural and social scientists and science communicators have been quite vocal in expressing their worries about the spread of hype and misrepresentations about epigenetics in the advertising of alternative health, well-being and nutritional products (Staropoli, 2017; Henikoff \& Greally, 2016; Greally, 2015b; Meloni, 2014b). In contrast, there has been only sparse reflection on the spread of hype and potential misconceptions about epigenetics in social science academia itself, where epigenetics is used to sketch out alternative theories and practices (but see Dubois, 2017; Dubois et al., 2018).

Both advertisers and academics are lay 'publics' with regard to epigenetics. They address further 'publics' (such as consumers and policy makers). It is therefore important to know what representations of epigenetics are disseminated in these contexts, as public understanding of epigenetics may shape individual and policy decisions about health. Views informed by social science academics and/or advertisers might come into conflict in the public sphere, or might, indeed, amplify each other. They might also clash with views by working scientists. This might have implications for interdisciplinary collaborations between social and natural scientists.

We shall now provide some insights into the conceptual background of our paper, focusing on social representations, metaphors and commonplaces, and, against this, describe the aims of this article. We shall then review the rise of epigenetics as a scientific topic, focusing on work by the scientists who first popularised this field. The main part of the paper will be devoted to setting out our sampling strategy and methods, our analysis and findings.

\section{Social representations, metaphors and commonplaces}

People make sense of the new by seeing it through the lens of the old. This also applies to novel concepts like 'epigenetics'. One way of doing this is through the use of metaphors and so-called 'commonplaces'. In this process people create 'social representations'. In the 
following we shall briefly discuss social representations, metaphors and commonplaces and how they are linked together.

A social representation is a system of values, ideas and practices regarding a given social object, in our case a scientific one, as well as the use of that object by a group for the purpose of communicating and behaving. It provides a given group with a shared social 'reality', 'common sense' and 'common consciousness'. Social representations may vary over time and between people. The primary function of a social representation is to allow 'something unfamiliar and troubling, which incites our curiosity to be incorporated into our own network of categories and allows us to compare it with what we consider a typical member of this category' (Moscovici, 1981: 193). Social representations theory was inaugurated by Serge Moscovici in the 1960s and is widely used to understand the way science circulates in society (Jaspal \& Nerlich, 2017).

Moscovici (1988) postulated two socio-psychological processes in the formation of representations: 'anchoring' and 'objectification'. Anchoring reflects the categorisation of unfamiliar objects through their comparison with an existing stock of familiar and culturally accessible objects. Objectification is the process whereby unfamiliar and abstract objects are transformed into concrete and 'objective' common-sense realities. Moscovici and Hewstone (1983) postulated three sub-processes associated with objectification, namely 'personification', 'figuration' and 'ontologisation'. We focus on the process of 'figuration', that is, on the objectification of aspects of epigenetics through metaphors and commonplaces.

Abric (2001) has outlined the structure of social representations, consisting of a core and peripheral elements. The central or structuring 'core' of the social representation attributes meaning and value to its other elements and determines the nature of the links between these elements. The 'core' unifies the representation and is its most stable element in moving and evolving contexts, while peripheral elements are organised around the core, and provide it with context.

The way in which lay publics make sense of science may differ among people (in this case advertisers and academics), both in terms of metaphors used, as well as in the distribution between core and peripheral aspects of the social representation. This highlights the need for fine-grained qualitative analyses of emerging metaphors and commonplaces (Jaspal \& Nerlich, 2017).

To study how academics and advertisers make sense of epigenetics, we used qualitative metaphor analysis. This is a semantic text analysis technique rooted in conceptual metaphor analysis (Lakoff \& Johnson, 1980) concerned with revealing latent meaning rather than a thematic technique concerned with the manifest meaning of text (Ignatow \& Mihalcea, 2017: 99). This type of analysis is used to 'gain insights into the divergent ways individuals and social groups come to interpret the social world' (Ignatow \& Mihalcea, 2017: 97). Conceptual metaphors reveal overarching and conventional patterns of thought of a group or society, what social representation theory calls 'figuration'. For example, 'Migrants are floods' is a conceptual metaphor that structures current political discourse in Europe and the United States and is regarded as 'common sense' by some groups. 
Understanding something unfamiliar, such as epigenetics, also relies on seeing it through the lens of what Max Black, one of the most prominent philosophers of metaphor, called a 'system of associated commonplaces' (Black, 1955). What are 'commonplaces' and why are they important in public understanding of science? Black wrote:

'Let us try, for instance, to think of a metaphor as a filter. Consider the statement, 'Man is a wolf'. Here, we may say, are two subjects: the principal subject, Man (or: men) and the subsidiary subject, Wolf (or: wolves). Now the metaphorical sentence in question will not convey its intended meaning to a reader sufficiently ignorant about wolves. What is needed is not so much that the reader shall know the standard dictionary meaning of 'wolf' - or be able to use that word in literal senses - as that he shall know what I will call the system of associated commonplaces. Imagine some layman required to say, without taking special thought, those things he held to be true about wolves; the set of statements resulting would approximate to what I am here calling the system of commonplaces associated with the word 'wolf' [...]. From the expert's standpoint, the system of commonplaces may include half-truths or downright mistakes (as when a whale is classified as a fish); but the important thing for the metaphor's effectiveness is not that the commonplaces shall be true, but that they should be readily and freely evoked.' (Black, 1955: 286-287)

Commonplaces shape understanding of the world and of what counts as 'common sense' in public understanding of science. In this article, we want to determine which system of commonplaces is readily and freely associated with 'epigenetics' by advertisers and social science academics. As the system of commonplaces may include half-truths or downright mistakes, we shall be on the lookout for these. This is important, as the lay people we study are disseminators of messages that influence other lay people, and therefore also public understanding of epigenetics and mutual understanding across disciplines.

Commonplaces and common-sensical understandings are themselves influenced by texts and talks produced by 'visible scientists' (Goodell, 1977), that is, prominent 'champions' (Tolwinski, 2013) of certain approaches to epigenetics. This means that we also have to explore how systems of social representations and associated commonplaces are shaped by (contested) visions of epigenetics popularised by visible scientists.

In the communication between science and society, metaphors and commonplaces first used in science open up a common ground for different lay participants in a debate. This common ground, marked out by a metaphor that filters our perceptions of the topic, can then be discussed, contested or accepted. Metaphors are 'nomadic 'messengers of meaning' (Maasen \& Weingart, 2013) and, by travelling through different forms of communication, they connect various scientific and non-scientific discourses. In our cases metaphors and commonplaces used by visible scientists are selected and modified by advertisers as well as academics. In the process epigenetics itself becomes something like a metaphor for a better life and for a better social science.

Aims

Keeping this in mind, we aim to: (1) Determine the meanings and social representations of epigenetics in (social science) academia and in advertising, based on the (promotional) use 
of metaphors and commonplaces that are available in the current scientific and cultural context; (2) compare and contrast them; (3) assess whether these meanings, metaphors and representations contain half-truths or downright mistakes (Black, 1955) and could create (ethical, communicational) problems for wider publics and scientists themselves (Nelkin, 1994) (we shall not focus on policy, as others have done this: Wastell \& White, 2017); and (4) discuss the implications of these social representations for interdisciplinary collaborations between natural and social scientists.

Addressing these aims requires some additional background on the rise of epigenetics in science and especially in society, the work done to popularise the field by champions of epigenetics in the natural and social sciences, and the parallel evolution of scientific and public perceptions of epigenetics. We shall now provide some background against which our analysis will take place.

\section{Background: The rise of epigenetics in science and society}

Epigenetics has a long history, but only started to gather momentum in its modern guise after the completion of the Human Genome Project in 2003 (see Figure 1).

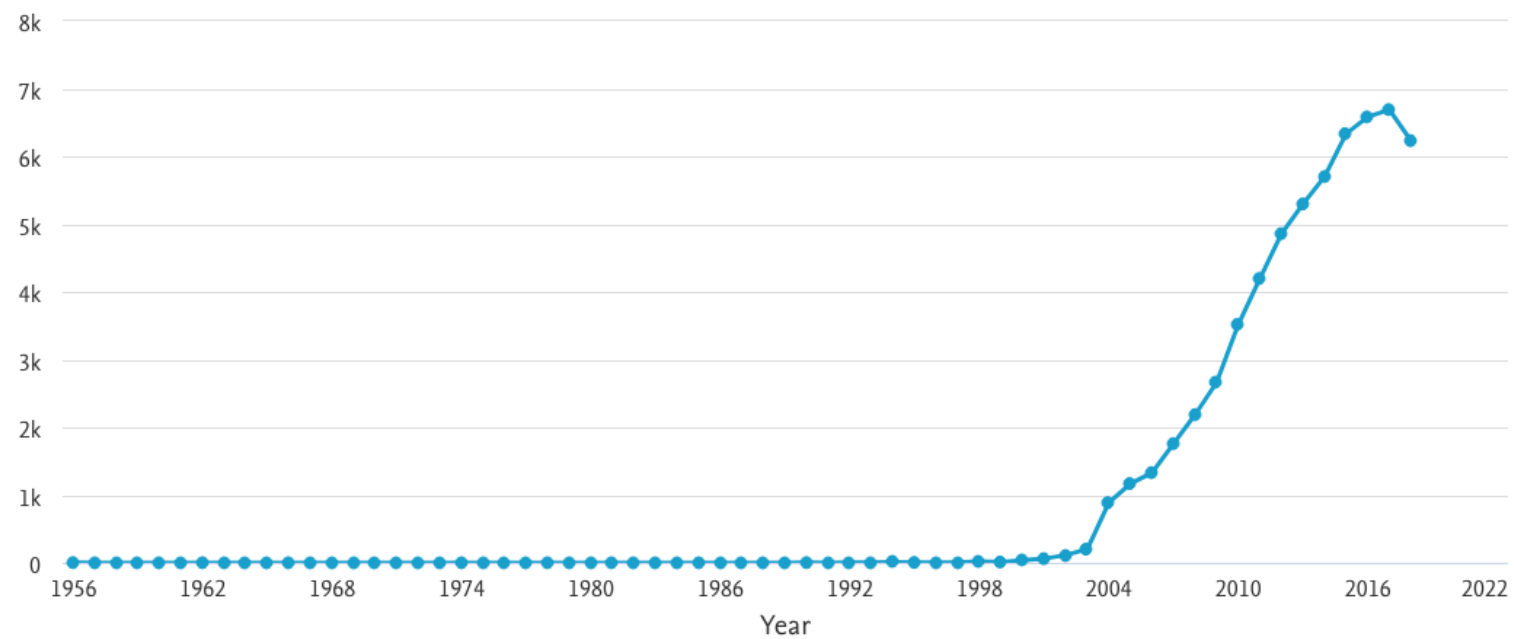

Figure 1: Documents containing the search term 'epigenetics', as retrieved on Scopus up to the end of $2018(60,273$ documents overall).

As epigenetic science began to flourish, scientists started to popularise their findings, social scientists began to think about this new field, and advertisers started to use some findings for their purposes. In this section we provide an overview of the promotional work done by visible scientists whose claims supported the emergence of a rich network of seemingly commonsensical metaphors, clichés and commonplaces. We start with visible natural scientists and then look at work done by visible social scientists; there are of course overlaps between the two. It should also be stressed that this overview affords only a glimpse of a much wider spectrum of influence, hype and popularisation. 
In 2003, Robert Waterland and Randy Jirtle showed that in a specific genetic strain of mouse a mother's diet can change her offspring's colour and other physical characteristics (Waterland \& Jirtle, 2003). In 2007 Jirtle and Michael Skinner published a review of the evidence for epigenetic inheritance in the famous 'agouti mouse' model, entitled 'Environmental epigenomics and disease susceptibility' (Jirtle \& Skinner, 2007). The agouti mouse is something of a special case, in which the Agouti gene (which controls a number of traits including coat colour, body fat, and susceptibility to diabetes) is regulated by the epigenetic status of a transposon, or jumping gene, that spontaneously inserted into a nearby piece of DNA. It was recently demonstrated that this type of mouse 'metastable epiallele' occurs only rarely (Kazachenka et al., 2018). Nevertheless, the specific case of epigenetic inheritance observed in the agouti mouse has been perceived to be a generalisable phenomenon, and despite the fact that there was 'virtually nil evidence' it has 'made its way into genetics textbooks' (Yeager, 2019) and was covered widely in high profile media, such as The New York Times (Blakeslee, 2003).

Two other mouse studies grabbed popular imagination about epigenetics: an early study by Michael Meaney in 2001 entitled 'Maternal care, gene expression, and the transmission of individual differences in stress reactivity across generations' (Meaney, 2001a) and a study by Meaney, Moshe Szyf and others on 'Epigenetic programming by maternal behaviour' published in 2004 (Weaver et al., 2004). Work by Meaney and Szyf is headlined by McGill University as 'Breaking the bonds of genetic destiny' and the first sentence proclaims: 'The conventional view of genetics is steeped in fatalism' (McGill, n.d.). Epigenetics was posited as a way to overcome it. Szyf, a pharmacologist, and Meaney, a psychologist, collaborated on what came to be known as the pup licking study. Here is a popular representation of it:

'Some mother rats spend a lot of time licking, grooming, and nursing their pups. Others seem to ignore their pups. Highly nurtured rat pups tend to grow up to be calm adults, while rat pups who receive little nurturing tend to grow up to be anxious.

It turns out that the difference between a calm and an anxious rat is not genetic, it's epigenetic. The nurturing behavior of a mother rat during the first week of life shapes her pups' epigenomes. And the epigenetic pattern that mom establishes tends to stay put, even after the pups become adults.' (Learn.Genetics, n.d.)

Highly speculative implications for human behaviour and even social policy began to circulate widely (Wastell \& White, 2017). Around that time, Marcus Pembrey published an article entitled 'Time to take epigenetic inheritance seriously' (Pembrey, 2002). By epigenetic inheritance we refer to both intergenerational (germline of next generation exposed to same environment as parent, e.g. in utero) and transgenerational (no direct exposure) inheritance. Transgenerational epigenetic inheritance became a focus of speculation in science and society, especially social science and advertising. Szyf, for example, wrote in 2015: 'The prospect that ancestral experiences are written in our epigenome has immense implications for our understanding of human behavior, health, and disease' (Szyf, 2015), using the metaphor of 'writing', common in genetic and genomic discourse - 'writing' that it was hoped epigenetics could 'erase' (see Stelmach \& Nerlich, 2015). 
These and other scientists began to talk about epigenetic insights derived from 'natural experiments' such as studies of twins, famines (e.g. Heijmans et al., 2008), the Holocaust (Yehuda et al., 2016) and natural disasters (Cao-Lei et al., 2014), which seemed to show that nutritional or emotional trauma had various effects on subsequent generations. They disseminated their findings not only at academic conferences but also in books, talks and videos, and thus made epigenetics visible to the general public and to social scientists.

In 2006 a popular magazine article titled 'DNA is not destiny: The new science of epigenetics' (Watters, 2006) quoted Jirtle as saying: 'Epigenetics is proving we have some responsibility for the integrity of our genome [...]. Before, genes predetermined outcomes. Now everything we do - everything we eat or smoke - can affect our gene expression and that of future generations. Epigenetics introduces the concept of free will into our idea of genetics.' It also quoted one of the most active popularisers of epigenetics, Szyf (2016), who uses YouTube to promote the view that epigenetics can help us change our genetic destiny.

Szyf gave a TED talk in 2016 entitled 'Epigenetics - Our bodies' way to change the destiny written in our DNA' (Szyf, 2016); as of September 2018, the video had attracted more than 1.3 million views on the TED Talks website and another 36,000 on YouTube. A talk for a healthcare summit in 2018 claimed that: 'Dr. Moshe Szyf, CEO of HKG Epitherapeutics, argues that DNA is more than a sequence of letters, but something that our life experiences can rewire. In spite of the deterministic nature of genetics, you have control of the way your genes look' (Szyf, 2018). Such talk became commonplace, indeed 'a commonplace', in many adverts for epigenetic products and self-help advice. 'Genes are not your destiny' became a core promotional metaphor. Social scientists in turn paid renewed attention to a critique of genetic determinism, an issue widely discussed during the Human Genome Project (Zwart, 2016).

One claim, namely that epigenetic changes can be passed down over generations, including changes induced by trauma and other 'social experiences', has however been contested by many working scientists (Greally, 2015a; Greally \& Drake 2017; Mitchell, 2018), and some authors are actively pushing back against popular overinterpretations of their work (Yehuda et al., 2018). However, their earlier conclusions seem to 'stick' in popular and social science memory - they circulate as collective and commonsensical social representations.

Carl Zimmer, a renowned science writer, has warned in an interview:

'The possibility of epigenetic inheritance is intoxicating because it raises the possibility that experiences can produce biological changes that are then passed down to future generations. It has completely taken popular culture by storm. We now have epigenetic skincare, epigenetic yoga... I've seen a book by a psychotherapist claiming that you can heal your psyche by treating the traumas of your grandparents that have been passed down to you.

But there's a lot of scepticism in the scientific community about the evidence for it in humans. The experiments are tantalising, but the studies are small, the effects are 
small, they haven't been replicated, and they really strain the imagination because you have to rethink a lot of basic biology just to make the idea work.' (Ball, 2018)

At the same time as scientific and pseudoscientific popularisers began to spread the word about epigenetic research, social scientists began to proclaim that mainstream genetics and evolutionary theory, especially the so-called modern evolutionary synthesis, was in crisis (Dupré, 2012; Meloni, 2014c) and that this opened a door for rethinking relations between biology and sociology. As Landecker and Panofsky (2013) pointed out: 'Although molecular epigenetic research is highly biochemical, it is of interest to sociologists because some epigenetic changes are environmentally mediated and can persist across the lifespan or into further generations' (Landecker \& Panofsky, 2013: 333). The assumption that epigenetic changes can be passed to further generations became the 'common sense' backdrop against which social scientists explored epigenetics.

While reading work by Meaney and Szyf for example, many social scientists were also perusing earlier research by interdisciplinary scholars such as Eva Jablonka, who helped make a certain version of epigenetics, focusing on epigenetic inheritance, popular (see Jablonka \& Lamb, 1995). As a recent BBC World Service programme discussing 'Big Ideas' said: 'At the forefront of establishing epigenetics as a big idea is Eva Jablonka' (BBC, 2018). She is aware of the hype surrounding epigenetics but also believes that it rightly challenges old genetic dogmas (Jablonka, 2016) and that 'acknowledging the existence of epigenetic inheritance renders the classical nature-nurture dichotomy obsolete, because it means that heredity ('nature') can be developmentally constructed ('nurtured').' This means 'an epigenetic perspective blurs traditional distinctions such as those between nature and nurture, plasticity and evolvability'. Jablonka claimed that '[s]tudying epigenetics can forge new experimental and conceptual bridges between biology, the social sciences and the humanities' (Jablonka, 2016). Many scholars responded to such calls and immersed themselves in the world of epigenetics that began to circulate in the public sphere.

Against this background, we analysed social representations of epigenetics in advertising and (social science) academia, where some of the same talking points put forward by visible social and natural scientists are used, albeit for different purposes. We shall first discuss our sampling strategy and method, before describing the analysis and then discussing what our findings mean for collaborations between natural and social scientists.

\section{Sampling strategy and method}

\section{Social science samples}

For the analysis of the use of epigenetics in the social sciences, we queried Scopus to identify the top (i.e. most prolific) authors in the field and decide how to constrain our sample. Scopus is 'the largest abstract and citation database of peer-reviewed literature: scientific journals, books and conference proceedings' (Elsevier, n.d.).

On August $3^{\text {rd }}, 2018$, we searched for 'epigenetics' overall which gave us 53,508 documents from 1956 to the end of 2017. The top authors were Manel Esteller (cancer epigenetics) and Moshe Szyf (pharmacology). According to Scopus, Esteller has not been cited by social science/humanities authors, but Szyf has. 
We then looked at the distribution of disciplines. Biochemistry and medicine dominate, but within the 'multidisciplinary' segment we found articles on epigenetics and 'social science' (413) and epigenetics and 'arts and humanities' (344). The top author in the social sciences was Maurizio Meloni (social theory), followed by Margaret Lock (anthropology). In the arts and humanities segment, the top author was, surprisingly, Michael J. Meaney, followed by the philosopher John Dupré (philosophy of science), and, again, Lock.

While studying authors like Lock and Meloni, we also noticed the emergence of epigenetic and biosocial concepts in education, one of the latest additions to a vast network of biosocial and epigenetic thinking in the social sciences (see Meloni et al., 2018a; Pickersgill, 2019). This use of epigenetics to reform education 'biosocially', especially in light of social justice issues, is promoted by the sociologist of education Deborah Youdell who has recently published a book on this matter (Youdell \& Lindley, 2018).

An intense interest in epigenetics has spread through the social sciences and beyond (Dupras, 2017), from sociology and science and technology studies to material feminism, from criminology to bioethics, from the history and philosophy of science to policy analysis, from anthropology to education. As we can't study the whole field, we drill down through three places (social theory, anthropology and education). Future work will have to spread the net of analysis more widely. We shall study Meloni's early articles (one co-authored with a natural scientist) which promoted and popularised epigenetics within the social sciences (Meloni 2014a, 2014b, 2014c, and Meloni \& Testa, 2014), as well as a handbook introduction to the studies of the 'biosocial' (Meloni et al., 2018b).

Meloni's work was partly influenced by Lock's foray into epigenetics in the context of medical anthropology (see Meloni et al., 2016: 11), especially her concepts of 'local biologies' (Lock \& Nguyen, 2010: 90) and the related concept of 'embedded bodies' developed by Jörg Niewöhner (2011). Lock has now summarised her thoughts on epigenetics and anthropology in a chapter on epigenetics for a handbook on genomics, health and society (Lock, 2018a). We shall therefore mainly focus on this chapter, which appeared in Part 4 of the handbook entitled 'Crossing boundaries', as well as some earlier work, such as Lock (2013) in which she sets out to chart new directions for (medical and social) anthropology, and two recent articles on situated biologies (Niewöhner \& Lock, 2018), and on permeable bodies (Lock, 2018b).

In the case of Youdell, we shall, as with Meloni, not analyse whole books but focus instead on some of the articles leading up to her book (Youdell, 2016, 2017) and in particular on her contribution to a handbook on biology and society (Youdell, 2018).

All three authors attempt to use epigenetics to promote a new agenda of research in sociology/social theory, (medical) anthropology and education, respectively.

\section{Advertising and marketing samples}

For the study of advertising on Twitter we relied on a qualitative approach which allows researchers 'to investigate the practices of a particular user group, as it can go beyond tracking follower counts or hashtag use to include many more sources of input about a specific community or user segment' (Marwick, 2014: 110). 
By advertising we mean promotion of products and services, or philosophies that in turn incite interest in products or services. We found tweets promoting tangible products, such as epigenetic creams, supplements, and cookbooks, as well as services, such as epigenetic diet and fitness plans, epigenetically inspired wellness and coaching services, and epigenetically inspired men's health therapies and vision treatment. Epigenetics was also used to promote alternative health therapies, such as epigenetic healing (especially healing the 'trauma of past generations'), meditation, 'quantum' alternative therapies, etc. Some tweets used the theme of epigenetics to advertise various 'philosophies', such as ideas promoted by Bruce Lipton, Deepak Chopra or the Institute for Creation Research and in turn these people and institutions advertised their own products and services, such as books, talks, workshops, etc.

In order to investigate tweets and texts of one particular user group - the advertisers - we opted for the 'small data, thick data' strategy of qualitative analysis of Twitter (Latzko-Toth et al., 2017) which favours samples small enough for in-depth textual analysis (see also Marwick, 2014: 118), but sufficiently rich or 'thick' to be representative of the studied question or phenomenon (Latzko-Toth et al., 2017). Rather than being retrieved through algorithms, 'thick data' samples rely on manual collection of digital material which 'encourages exploration and fosters greater familiarity with the traces in their 'native' format, as they are envisioned by social media users' (Latzko-Toth et al., 2017).

This strategy is complemented by a long-term observation of online activities, such as following Twitter accounts and hashtags (keywords), which allows for a quasiethnographic immersion in the topic and fosters a better understanding of the studied phenomena (see also Marwick, 2014: 118).

We followed the feed of the Twitter hashtags 'epigenetic' and 'epigenetics' for 2018. We manually extracted tweets promoting novel ways of healing and well-being. We discussed tweets we found metaphorically interesting and collected a sample of 70 tweets for in-depth analysis. We treated the tweets as texts, but, more importantly, we studied in detail the texts 'underneath' them, that is, the blog posts, articles, or websites that they advertised. In the following we can only showcase a few illustrative examples. There are many more tweets and websites out there that deserve to be studied in the future.

\section{Analysis}

\section{Analysis part 1: Social science and epigenetics}

Many social scientists engage with epigenetics in order to establish a new social science of the 'biosocial' (Ingold \& Pálsson, 2013), a venture that, ideally, also involves collaborations with natural scientists (Pickersgill et al., 2013; Chung et al., 2016). This focus on the biosocial has also become popular with funding agencies (Economic and Social Research Council, n.d.; Russel Sage Foundation, n.d.) that encourage collaboration between social and natural scientists. A definition of the biosocial is provided in a book edited by a group of social scientists (Meloni et al., 2016): 'This novel biosocial approach [...] challenges the reductionisms of sociobiology and cultural constructionism alike (dissolving the pole of nurture into nature and vice versa, respectively), and puts forward an integration of 'the social and the biological [...] ontogeny and phylogeny, organism and context, being and 
becoming' (Ingold \& Pálsson, 2013: 243)' (Meloni et al., 2016: 11). This is contrasted with 'the continuing persistence of older deterministic views' (Meloni et al., 2016: 18).

Promoting new fields relies on boundary-work (Gieryn, 1983) which often draws on rhetorical devices such as metaphors (Bucchi, 1998). To establish a place for the new studies into the 'biosocial', this boundary-work is performed by drawing various temporal and conceptual divisions in order to then show how they can be overcome. In our case, dichotomies and distinctions cluster around a central metaphor, that of the 'boundary' itself. The most important distinction is made between traditional genetic and genomic science and 'post-genomic' science, i.e. a type of genomic science that came after the completion of the Human Genome Project and the start of the Human Epigenome Project around 2003. From the central metaphor of the boundary/barrier/divide and the distinctions surrounding it follows a number of 'commonplaces' relating to the rejection of old views of genetics and positing new views of heredity.

Before we analyse metaphors and related commonplaces, it should be stressed that social scientists are aware of difficulties relating to transitioning from pre- to postgenomics, from pre-epigenetic social science to post-epigenetic social science, and thus to a new study of the biosocial. They are also aware of the many ambiguities surrounding epigenetics (Meloni \& Testa, 2014; Lloyd \& Müller, 2018) and of hype and contestation surrounding this new field (Lock, 2013; Meloni, 2014b). Despite this, it is claimed that epigenetics opens 'for social theory unique entry points', as it seems to blur the boundaries between the social and the biological (Meloni \& Testa, 2014: 433; for a critique see Deichmann, 2017: 291). Epigenetics is used here to do something, in this case, sociological theory-building or to induce a 'paradigm shift' 'in which environments external and internal to the body are recognised as initiating and sustaining human life, development, well-being and malaise over the life course' (Lock, 2018a: 252) or to engage in 'advocacy of biosocial education research and practice' (Youdell, 2017: 1274).

All three authors, Meloni, Lock and Youdell, use the metaphor of overcoming of boundaries, between body and environment, nature and nurture or boundaries of social differences to advance their epigenetically inspired agendas. Meloni does this explicitly, Youdell implicitly.

We shall now explore the central metaphor of the 'boundary' - the core social representation structuring some social science understanding and use of epigenetics together with its implied other, namely the metaphor of the 'bridge'. We shall then study two crucial, but more peripheral, metaphors that support this central metaphor, namely that of the 'gene as plastic' and that of 'genetic memory', before homing in on a variety of theoretical commonplaces associated with these metaphors. Here again we can draw a distinction between a core commonplace, that of transgenerational epigenetic inheritance and more peripheral ones.

The central metaphor and its other: 'Boundaries' and 'bridges'

Metaphors are crucial for social theorising (López, 2003), and the conceptual metaphor of 'boundary' constitutes a common resource for interdisciplinary theory-making across the social sciences (Lamont \& Molnár, 2002: 167). It has also become a cliché in popular debates about disciplinary divides (Snow, 2001[1959]). 
We first became aware of the importance of the boundary metaphor in social science discussions of epigenetics when reading an introduction to a handbook on the biosocial (Meloni et al., 2018a). The first sentence says: 'For many decades, the study of society and the study of biology have been estranged from one another' (Meloni et al., 2018a: 1). This postulated estrangement is, it is claimed, the result of, firstly, 'biologists' dealing with 'genes' in a certain narrow way and, secondly, of 'social scientists' dealing with the relationship between the sciences of society and the life sciences in a certain way namely by making a 'strict division of labour' between them. This claim is reinforced when we read about a 'binary opposition', a 'symmetrical hostility' (Meloni et al., 2018a: 2) and a 'prevailing metaphysics that drives a wedge between biology and society' (Meloni et al., 2018a: 3). This language is echoed in other texts talking about 'years of mutual antagonism' (Meloni, 2014a: 593), of a 'great divide' (Meloni, 2014a: 608), even a 'membrane' separating biology and society/sociology (Meloni, 2014a: 603).

The handbook introduction uses various phrases indicating how this barrier can be overcome, such as 'the transactions between biology and sociology' (Meloni et al., 2018b: 7), 'at the crossroads of the social and biological' (Meloni et al., 2018b: 7), 'a potential bridge between the social and the natural sciences' (Meloni et al., 2018b: 8) (see also Jablonka, 2016; for empirical explorations of such bridges, see Lloyd \& Müller, 2018). Such bridges can, it seems, be found in neuroplasticity and epigenetics, for example. The handbook's 'central assertion' is that 'the life sciences, broadly conceived, are currently moving towards a more social view of biological process, just as the social sciences are beginning to reincorporate notions of the biological body into their investigation' (Meloni, et al., 2018b: 2).

The aim for the social sciences should be to breach or renegotiate these sociobiological boundaries (Meloni, 2014a: 593), taking advantage of the fact that, with the advent of epigenetics, they are now becoming blurred, permeable (Meloni, 2014a: 603; Niewöhner \& Lock, 2018: 690) and are on the verge of collapse (Meloni \& Testa, 2014: 450); epigenetics foregrounds 'entanglement', a central concept in Science and Technology Studies, rather than division (see title of Youdell and Lindley's 2018 book and title of Niewöhner and Lock's 2018 article).

Boundaries are seen as 'productive' (Meloni \& Testa, 2014: 436), in the sense of providing an opportunity to rethink, indeed 'revitalise' the way sociology deals with biology (Fitzgerald et al., 2016). Niewöhner and Lock therefore 'set out from the position that building effective bridges between the social and biological sciences is a matter of some urgency' (2018: 681) in order to 'reopen' spaces 'closed down' by the Human Genome Project for example.

Epigenetics is posited as not only overcoming conceptual boundaries, but also the barrier between the body and the environment. It is seen as going 'beyond', i.e. 'epi', the (fixed, rigid, deterministic) gene. The definition of epigenetics as 'beyond' genetics is generally used in the social science literature (see Lock, 2018a: 246) (and now encapsulated in a recent book titled Above the Gene, Beyond Biology: Toward a Philosophy of Epigenetics (Baedke, 2018)), but is criticised by some working epigenetic scientists who are rather critical of this 'backtranslation' (see Nerlich \& Stelmach, 2018). As David Haig pointed out, 
epigenetics has 'an enduring appeal for critics of genetic orthodoxy, because the word's structure had connotations of being 'above' or 'beyond' genetics' (Haig, 2012).

Metaphorically, epigenetics is often defined as being able to explain how the social and the cultural 'gets under the skin' (Yearley, 2012), a phrase that came to be called a 'cliché du jour' in social science circles (Callard \& Fitzgerald, 2015: 47). It is also used in Niewöhner and Lock (2018: 686) and the notion of the permeable body (together with mutable environments) is used extensively in Lock (2018b). It has become commonplace to say that 'epigenetics has been defined as the biological proof of 'how the social gets under the skin" (Meloni, 2014c: 732). This metaphor is not only used by social scientists though; it can also be found in articles by natural scientists (Nerlich, 2016).

In a recent article on the 'postgenomic body', Meloni writes (quoting Landecker \& Panofsky, 2013 and referencing Meaney's work): 'By showing how various material instantiations of social life (toxins, food, stress and socioeconomic status) become literally embodied in the epigenome, epigenetics is said to illustrate how the environment gets inside the body and makes 'the boundary of the skin of little significance" (Meloni, 2018b: 4; see also Niewöhner \& Lock, 2018 for similar arguments).

Boundaries and bodies are explored more extensively by Lock in her work in medical anthropology. She focuses on the 'entanglement' between bodies and environment as well as the intertwinement of nature and nurture and states 'that nature/nurture is entangled and not divisible' (Lock, 2018a: 218). Referencing Meloni, Youdell writes that 'there is emerging evidence in epigenetics of the ongoing and persistent enfolding of the social into the biological' (Youdell, 2017: 1274) and: 'Epigenetics means that biological and the social are not separate after all.' (Youdell, 2016: 54).

Historically, such boundary metaphors are claimed to be rooted in the 'Weismannian barrier' (Meloni, 2014a: 604). August Weismann was 'one of the founders of the science of genetics, who is best known for his germ plasm' theory, and opposition to 'the idea of inheritance of acquired characters'. He proposed 'the principle that hereditary information moves only from genes to body cells, and never in reverse' (Beale, 2019).

A central claim running through most of the social science writing on epigenetics is that 'boundaries' of every kind (conceptual, historical, corporeal) have been shaken by the advent of epigenetics. The new, epigenetically informed biology makes 'the biology/society boundary increasingly difficult to patrol and the entwinement of biological and social facts a reality that is difficult to avoid' (Meloni, 2014c: 732). This means that 'the epigenetic body brings the Weismannian body to an end' (Meloni \& Testa, 2014: 454).

While Meloni links his boundary explorations and epigenetics centrally to Weismann and the metaphor of the barrier, Lock tracks the emergence of the nature/nurture divide to Galton (Lock, 2013), and she focuses more on one of the founding fathers of epigenetics, namely Conrad Waddington whose work and whose metaphor of the epigenetic landscape seems to bring nature and nurture, the genotypes and the phenotypes, or genes and environment closer to each other (Lock, 2018a). She claims that this metaphor was inspired by the work of the biochemist and sinologist Needham who studied 'traditional understanding of disease causation in China in which individual bodies are understood as ceaselessly striving to restore and retain equilibrium within the spheres 
of society, environment, and the cosmos in which they are embedded' (Lock, 2018a: 247). For Lock, the notion of embeddedness is central to her understanding of epigenetics.

Let us now look at the metaphors of embeddedness, entwinement, plasticity and permeability that replace the rigid boundaries postulated here.

\section{Metaphors of plasticity}

Some social scientists link the 'Weismann barrier', central to the boundary metaphor, to 'gene centrism' or 'genocentrism', which they regard as 'biologically fallacious (Meaney, 2001a)' (quoted in Meloni, 2014b: 1), as it is based on a 'dichotomous view of biology vs. society and biology vs. culture' (ibid.) (see also Van de Vijver et al., 2002; Dupré, 2010). In order to talk about this fallacy, the gene is metaphorically portrayed as having been seen in the past as 'a discrete and autonomous agent' (Meloni, 2014b); 'a distinct, particulate gene marked by 'clearly defined boundaries' and performing just one job, i.e., coding for proteins' (ibid.). Epigenetics by contrast 'deflate[s] the role of genes as causally privileged determinants of phenotypes' (Meloni \& Testa, 2014: 434). Epigenetics is also seen as challenging a perceived dualism between a static DNA and a dynamic epigenome (e.g. Griffiths \& Stotz, 2013; Lappé \& Landecker, 2015; Meloni, 2018b: 22, Lock 2018a: 248249).

This portrayal of traditional genomics (including the modern synthesis, neoDarwinism, etc.) as gene-centric can be found in works by early champions of the field of epigenetics, such as Meaney (2001a, 2001b), Szyf (2011) (who talks about the now discredited gene-centric focus in the approach to human diseases), and Spector (2012) (who decries the gene-centric view of the universe) (see Meloni \& Testa, 2014).

This gene-centrism is linked to 'established (i.e. biologistic) views of the biological as what is 'genetic', 'innate', 'prior to the social', 'essential', 'universal', and 'invariable" (Meloni, 2014c: 73). After the advent of epigenetics, the 'fixed or 'inert' gene/genome' is replaced by a different image of the gene/genome, metaphorically described as reactive, adaptive, temporalised or socialised, the gene in context, the gene as dynamic, plastic, flexible and so on (see Dupré, 2012; see Niewöhner \& Lock, 2018). These discussions link up with long-standing debates about brain plasticity (see Youdell, 2018: 301).

This also means rejecting the 'book of life' metaphor, used so successfully to popularise the Human Genome Project (see Niewöhner \& Lock, 2018), a metaphor challenged, it seems, by epigenetics. 'The inert genome is thereby supplemented by a softer, more adaptable, epigenome, incorporating mechanisms capable of responding to the environment, sensing 'time' and retaining 'memories" (Chung et al., 2016). This brings us to a third metaphor, that of epigenetic 'memory'.

\section{Metaphors of epigenetic memory}

This dynamic view of the gene and its entanglement with the environment and the body rests on two pillars of supposed evidence: new insights into gene regulation and gene expression (how genes are switched off and on) and new insights into genetic memory. Genes are supposed to lay down marks or 'memories' of environmental exposures and experiences that triggered genes to be switched on or off, and also to be able to pass these 'memories' on to the next and even further generations. 
Epigenetic marks or memories are postulated to have implications for individual health and possibly the (intergenerational) health of offspring, from conception onwards. Controversy surrounds any speculation about transgenerational inheritance of epigenetic marks or variations. This phenomenon has been shown to occur in plants, worms and rodents, but has not yet been definitively demonstrated in humans (see Grossniklaus et al., 2013: 228; Mitchell, 2018), in part 'because the study of transgenerational epigenetic inheritance is confounded by genetic, ecological and cultural inheritance' (Horsthemke, 2018). However, early epigenetic studies, such as those quoted by visible natural and social scientists, depicted human transgenerational epigenetic inheritance as a fact rather than a hypothesis, and thus attracted a lot of attention and speculation (Heard \& Martienssen, 2014; Häfner \& Lund, 2016).

In his seminal article on how 'biology became social', Meloni picks up the metaphor of genetic memory and weaves it together with epigenetic plasticity and the demise of a 'fixed' genome:

'Transient environmental factors can leave a biological trace and become parts of the 'memory' of the genetic material itself (and even be transmitted intergenerationally). From the viewpoint of evolutionary theory, epigenetic mutations are often seen as a case of developmental plasticity, the way by which a 'fixed genome' can respond in a more plastic and flexible way to the solicitations from a changing and dynamic environment' (Meloni, 2014a: 9).

Social scientists don't use the term 'genoplasticity', as some advertisers do (see 'Genoplasticity: Maximise your being ${ }^{1 '}$ ), but this term expresses exactly the spirit of their opposition to older genetic traditions. Some social scientists, such as Youdell, go as far as to extrapolate from animal models showing some contested epigenetic effects to classroom learning: 'Epigenetic research using animal models also shows the potential significance of nurturing relationships for learning' (Youdell, 2018: 309).

As we have seen, social scientific work on epigenetics uses one central and two peripheral metaphors. The central metaphor is that of a 'barrier' that separates the biological and the social, while the two metaphors of plasticity and memory make this barrier porous, overcome 'gene-centrism', and open it up for an exploration of the 'biosocial' as an integrated phenomenon. This social representation, with its argumentative core supported by (peripheral) evidence, makes epigenetics useful for social scientists who want to close a perceived gap between the sociological and the biological.

In this context epigenetics is regarded as 'good to think with' (see Niewöhner \& Lock, 2018: 685), a phrase coined by Claude Lévi-Strauss, who 'used' animals to think about new anthropological contexts. Epigenetics here serves a similar intellectual and speculative function. It is used to renew debates in sociology, anthropology and education, and not necessarily to dissect the science of epigenetics itself. Thus, epigenetics is 'used' as a promotional tool to signal new intellectual agendas, i.e. building bridges between disciplines and topics, even though little is yet known about how these bridges might function, and how this new research should be conducted (see Dubois et al., 2018).

\footnotetext{
${ }^{1}$ Available at: http://genoplasticity.org/
} 


\section{Associated commonplaces}

Related to this cluster of metaphors are a number of commonplaces which are theoretically central to making these metaphors work. All commonplaces are linked to some extent to an acceptance of the controversial hypothesis of transgenerational epigenetic inheritance, which constitutes a core commonplace underpinning social scientific thinking and metaphor-making in relation to epigenetics, as it seems to 'bridge' 'barriers' between past and future, gene and environment, nature and nurture, genes and behaviour, and so on.

In the following we encapsulate these commonplaces as pronouncing various views as 'dead' - this is a metaphorical framing of our empirical findings, and not, with one exception, that of the authors studied.

The first commonplace related to the core metaphor of the barrier is:

- The dichotomy between the biological and the social is dead (and should be replaced by a sociology and biology of the biosocial).

Linked to this are four other commonplaces - all linked to the assumption that 'genecentrism' is dead:

- The Central Dogma is dead (and should be replaced by a new post-genomic theory);

- The theory of neo-Darwinian evolution is dead (while neo-Lamarckism is alive);

- Genetic determinism/fatalism is dead (instead we can exert control over our genes, indeed our future, through individual/lifestyle actions or collective/policy actions)

- Genetic reductionism is dead (but epigenetic reductionism is still alive).

\section{The Central Dogma is dead}

In discussions about molecular biology, the so-called Central Dogma of biology is declared 'dead' on a regular basis, including after the advent of epigenetics (see Moran, 2007). It is indeed a metaphorical commonplace. In the context of epigenetics, this is linked to the promotional metaphor of the barrier, as the following quote shows (although the Weismann barrier should not be confused with the Central Dogma, see Noble, 2018):

'In epigenetic research, the 'social' seems to assume a causative role in human biology to a degree unseen before (Landecker \& Panofsky, 2013). [...] Such a discourse was quite unimaginable under the Weismannian's conception of an impenetrable barrier between soma and germ-line, as well in what can be seen as the molecular translation of Weismann's argument [...] in the so-called Central Dogma of Molecular biology [...] which stated the strict one-side flow of information from DNA to RNA2.' (Meloni, 2014b)

This social representation of epigenetics rejecting the Central Dogma comes however into conflict with numerous scientific representations of the Central Dogma which are more nuanced and where its 'death' is very much disputed (Morange, 2008).

\footnotetext{
${ }^{2}$ RNA is a single-stranded molecule similar to DNA that plays multiple roles within cells, including as an intermediate step in the production of proteins from the DNA sequences encoded in genes (authors'note).
} 
Likewise, epigenetic commentators are excited by the discovery that some proteins and small RNAs help to regulate epigenetic marks. However, these phenomena do not affect the actual DNA sequence. 'Despite recent excitement about transgenerational epigenetic inheritance due to histone modifications, DNA methylation, or other temporary modifications of material surrounding the genetic sequence, there is no evidence in any organism that the information in a DNA sequence can be rewritten from information in a protein' (Cobb, 2017).

Given what we know about the Central Dogma and epigenetics, it might be premature to posit epigenetics as an antithesis of genetics and as the basis for an alternative paradigm (Morange, 2002). Pronouncements that 'a genetic view of life in its strongest sense - sequestration of genetic material from the environment, the Central Dogma and so on' (Meloni, 2018a) has now been shaken by developments such as epigenetics, therefore have to be taken with a pinch of salt (Maderspacher, 2010: R836; Scott-Phillips et al., 2011: 44).

Neo-Lamarckism is alive (while neo-Darwinism is dead)

Some modern philosophers of biology have proposed a new theory of evolution and heredity and replace neo-Darwinism (which is declared 'dead' by some; see Ingold, 2013: 1) with a nod to neo-Lamarckism (that acquired characteristics can be passed on to offspring) and the possibility of transgenerational genetic inheritance of 'acquired traits' (Bohacek et al., 2018; Bonduriansky \& Day, 2018). This is a move from so-called 'hard heredity' (Meloni throughout; Youdell, 2018: 307) to 'soft heredity'3.

Meloni refers to scholars proposing alternatives to traditional genomics as 'heterodox' (Meloni, 2014b) and as 'heretics' (Meloni, 2018a). They are celebrated as rebelling against an old orthodoxy, which is, in a way, portrayed as 'dogmatic'.

While Lock does not support the view that epigenetics overturns Darwinism, she agrees that some aspects of Lamarck's thinking are relevant for epigenetics, which gives this field a 'neo-Lamarckian' flavour (Lock, 2018a: 249). However, working scientists demonstrate in general a healthy scepticism about such claims (Dickins \& Dickins, 2008; Haig, 2007), and some claims are even ridiculed (Cobb, 2017, 2018).

Genetic determinism is dead

This topic has permeated early social science research on epigenetics (rooted in numerous social science studies arguing against genetic determinism during the heyday of genetics and genomics), but is now replaced by more nuanced positions, summarised in Schuol (2017). One can find, however, a rather hyperbolic/metaphorical rejection of this presumed 'determinism' when Meloni writes: 'Given the epistemological and political implications of gene-centrism and the mainstream view of biology as an unchangeable form of secular destiny in the twentieth century these more plastic biosocial approaches have remained so far exceptions' (Meloni, 2014b, italics added). Similarly, Lock argues that: 'A dynamic epigenetic network with a life of its own has been exposed that creates a context-dependent reactive system in which DNA is just one part. Thus, contingency

\footnotetext{
3 The relation between Lamarck, Lamarckism, neo-Lamarckism and epigenetics is complicated. For an overview of the intricate relations between these concepts, see Robison (2018: 77) and following.
} 
displaces determinism' (Meloni, 2018a: 249; see also Keller, 2014 and Niewöhner \& Lock, 2018: 689).

As we shall see, this commonplace is much more important to advertisers. It is also still important to visible scientists who over-hype their claims, as recent discussions around the book Blueprint by Robert Plomin have shown (Kaufman, 2019). The reception of this book has demonstrated that genetic determinism is roundly rejected by mainstream genetic and genomic scientists, as well as social science commentators.

The metaphors and commonplaces discussed here are important, as they enable the academics using them to dismiss the old and build the new. A by-product of this new way of doing social scientific research, based on a perceived new way of doing genetics and genomics, is the entrenchment of certain conceptions of epigenetics, some of which might be misconceptions in the eyes of those doing epigenetics.

\section{Genetic reductionism is dead}

Lock's work focuses specifically on discussions around genetic reductionism (which she opposes to the 'reunification' of nature and nurture: see Lock, 2013; see also Youdell, 2018). She claims that '[e]pigeneticists have thrown down the gauntlet to genetic reductionists but, even so, the full significance of social, economic, and political aspects of health inequalities remain distinctly shadowy' (Lock, 2013: 292). While the perceived shortcomings of reductionism are plainly laid at the feet of genetics and genomics, Lock was also one of the first to alert anthropologists to the dangers of 'somatic reductionism' brought about by epigenetics.

This critique of reductionism leads to some speculations about transgenerational epigenetic inheritance: 'An embedded body is not the product of interactions of nature and nurture but, by definition, is situated in an entanglement of nature/nurture that transcends generations, raising profound questions about concepts of self and body as clearly bounded entities' (Lock, 2013: 303). This focus on 'entanglement' in particular is also evident in the work of Youdell, who sees in epigenetics an opportunity to open up biosocial research focusing on social justice issues in the classroom environment.

\section{Analysis Part 2: Advertising and marketing}

In 2018 Steven Henikoff noted that: 'The term [epigenetics] has permeated popular culture, often as a marketing gimmick, such as 'epigenetic dentistry'. Excitement about epigenetics has also fuelled wishful thinking about controlling one's own genes through epigenetics' (Henikoff, 2018; also, Smith, 2012). In the following, we shall study a small sample of tweets or retweets, and examine the metaphors used in the tweet texts as well as in the blog posts, articles or website texts to which they link.

In the academic/social science articles we studied, we found a small number of metaphors (boundary/barrier/bridge, genes as rigid/flexible, and epigenetic memory), supported by several commonplaces (transgenerational epigenetic inheritance, the Central Dogma is dead, Lamarckism is resurrected, and references to a rejection of genetic determinism/fatalism/reductionism). When we looked at the advertising tweets and retweets, we found a configuration indicative of a slightly different web of social representations. 
Vivid metaphors based on older metaphors for genes and genomes were used to reject the Central Dogma and Darwinian evolution and toy with intelligent design and other forms of creationism (Coppedge, 2019). But, most importantly, we found a rejection of genetic determinism in favour of what one may call epigenetic self-determinism and control over genes. This seems to be the core social representation of epigenetics that advertisers use to sell their products.

\section{Metaphors rejecting genetic determinism}

\section{Genes as prisons and how to escape}

Some of the most vivid metaphors were used in an article (advertised in a tweet) posted on The Complementary Medical Association website with the prototypical title: 'Epigenetics you can rewrite your future ${ }^{4 \prime}$. Using a mixed metaphor, the article paints a stark image of genetic determinism and urges us not to believe that we 'are completely defined, limited and even imprisoned by the deck of genetic cards' we get dealt at birth. Using the metaphor of 'the genetic blueprint', it then tells readers that this blueprint might 'predispose you to any number of positive and negative conditions', but it is your choice how genes are expressed through the environment you create and live in. So far, so metaphorically normal. Then we get a nice new metaphor: 'You don't have to drown in your own gene pool!' The important message is that people can 'do' things that make their lives better, whatever their genes.

While the social science articles we studied used metaphors to urge social scientists to do things differently, indeed engage in what one may call alternative approaches to social scientific research, based on bridging the social and the biological, advertisers urge consumers to do things differently, indeed engage in alternative health behaviour, based on controlling the biological via the social. This issue of control over genes is also explored in the next metaphor.

\section{Genes as programmes and how to reprogramme them}

The metaphor of genes as programmes was frequently deployed in tweets, for example: 'How your mind and what you do to your body can reprogram your genes' and 'We're the programmers of the code DNA activation is our Software upgrade ${ }^{6 \prime}$. This is how we can 'repair' and 'heal' ourselves. Indeed: 'Epigenetics is a mechanism for DNA plasticity without changing the DNA sequence, and can be used to hack our own DNA with just our minds".

Social science academics extolled the plasticity, flexibility and dynamics of genes. Advertisers go a step further by telling people how to 'activate' them, how to 'recode' them and how to 'reset' genes 'to youth' ${ }^{8}$, especially the genes that control your skin. Here, 'getting under your skin' is taken literally, and the science of epigenetics is framed as

\footnotetext{
${ }^{4}$ Goddard J, 'Epigenetics - you can rewrite your future', The Complementary Medical Association. Available at: http://www.the-cma.org.uk/Articles/Epigenetics-you-can-rewrite-your-future-6183/

${ }^{5}$ Available at: https://twitter.com/HydropeptideUK/status/1021104603268616192

${ }^{6}$ Available at: https://twitter.com/Dorohotsinne/status/1019358309428670464

${ }^{7}$ Available at: https://twitter.com/ZZO/status/988074431200284674

${ }^{8}$ Available at: https://twitter.com/ken ragsdale/status/1026211778055823361
} 
capable of not only rejuvenating the body, but also of revitalising the wellness industry, as advertised by a tweet and an article about 'how epigenetics is enhancing the spa scene ${ }^{9}$.

Advertisers link a range of entrenched metaphors which have been used to popularise genetics and genomics in the past, from genes as blueprints to genes as programmes, something that social scientists did not do. However, both advertisers and social scientists hope that epigenetics will 'enhance', or indeed 'revitalise' (see Fitzgerald et al., 2016) respectively industry and social science.

\section{Genes can be switched on and off}

This message is linked to the switch metaphor that pervades popular descriptions of epigenetics (Stelmach \& Nerlich, 2015). Echoing social science discourse about 'rigid' genes, we find pronouncements linking the switch metaphor to that of a 'control panel' (or switch board), an image that entrenches the topic of 'control over your genes'. The following example comes from an article in Vogue advertised on Twitter:

'Proposing a more nuanced narrative than conventional wisdom about the immutability of our DNA, the epigenome has been identified as the control panel for our genes, determining which of them is turned on or off at any given time. [...] Environmental factors such as diet, stress, and sun exposure can affect the epigenome. As can time: A gene that plays an active role in producing a crucial protein for skin elasticity at age 20 may have powered down by age 40 . 'It's like a light switch [...]. If something is blocking that switch, you cannot turn the light on'10'.

Another example can be found on the pages of the Financial Times (pages, tellingly, called 'How to spend it') on epigenetic skincare capable of switching genes on and off ${ }^{11}$.

\section{Associated commonplaces}

\section{The issue of power and control}

These metaphors are associated with one central commonplace which was also the focus of some speculations by early champions of epigenetics: you can control your genes through epigenetics - and not only that, through your mind. This comes across very well in a tweet which defines epigenetics as 'the biology of belief, the power of the subconscious mind, the power of consciousness ${ }^{12}$. This view of genes is related to early work in epigenetics which proclaimed that genes are not your destiny, and it has been propagated in popular culture by alternative health promoters (see Mitchell, 2019).

\section{Transgenerational epigenetic inheritance}

\footnotetext{
${ }^{9}$ Available at: https://twitter.com/happyfication/status/976571141925015552

${ }^{10}$ Descantis $\mathrm{M}$, 'Can the genes responsible for aging be altered by a face cream? These skin-care companies say yes', Vogue, July 21, 2018 Available at: ,https://www.vogue.com/article/epigenetics-research-dna-geneexpression-smart-skin-care?mbid=social twitter

${ }^{11}$ Van der Post L, 'Epigenetic skincare: The creams switching off ageing genes', The Financial Times, December 28 2018. Available at:d https://howtospendit.ft.com/womens-style/205132-epigenetic-skincare-the-creamsswitching-off-ageing-genes

${ }^{12}$ Available at: https://twitter.com/RickyDaleBrown/status/1000218583027339266
} 
In some tweets and associated texts, epigenetic healing goes beyond the skin and even beyond the individual, as it may, it is claimed, reverse physical and mental 'trauma' passed down to generations. This belief in the healing power of epigenetics is based on a belief in transgenerational epigenetic inheritance ${ }^{13}$.

As the website The Best Brain Possible says: 'Epigenetic inheritance adds another dimension to the modern picture of evolution. It goes against the idea that inheritance happens only through the DNA code that passes from parent to offspring. It means that a parent's experiences, in the form of epigenetic tags, can be passed down to future generations ${ }^{14}$.'

This has implications for health and responsibility. One tweet says: 'Fun fact: Just like how you inherit traits physical through your DNA, you also inherit other aspects such as stress that affect your development and behavior, it's called epigenetics. So, be careful not to project your trauma onto your kids ${ }^{15}$.' The issue of stress has been studied in the context of biosocial research and epigenetics by Youdell and colleagues (Youdell et al., 2018) and the issue of 'responsibility' is also very much discussed in social sciences circles, but it goes beyond the scope of this article.

\section{The Central Dogma is dead}

It is noteworthy that some of the tweets and websites peddling alternative health claims based on epigenetics engage directly or indirectly with the critique of the 'primacy of DNA $^{16 \prime}$ and of genetics' so-called Central Dogma which, as we saw, is also a commonplace central to alternative sociologists interested in epigenetics. In this context, one webpage has to be mentioned. It is not in our sample, but it is something of a 'classic' and links to numerous other articles and YouTube videos by the same author as well as to several examples of alternative health claims (for a critique see_Gorski, 2013).

On this webpage a Dr Joseph Mercola states that 'epigenetics shatters the central dogma' and goes on to say:

'[Konstantin] Eriksen goes on to discuss something called 'The Central Dogma' of molecular biology, which states that biological information is transferred sequentially and only in one direction (from DNA to RNA to proteins).

The ramification of buying into the central dogma is that it leads to belief in absolute determinism, which leaves you utterly powerless to do anything about the health of your body; it's all driven by your genetic code, which you were born with.

However, scientists have completely shattered this dogma and proven it false. You actually have a tremendous amount of control over how your genetic traits are expressed - from how you think to what you eat and the environment you live in' (Mercola, 2012).

13 Available at: https://twitter.com/DrJackKruse/status/991699380863492097

14 'How trauma can damage the brain for generations and can be reversed', The Best Brain Possible, January 28, 2018. Available at: https://www.thebestbrainpossible.com/epigenetics-trauma-brain-reversed-mentalhealth/

15 Available at: https://twitter.com/ephrata/status/1026017123645108225

16 Available at: https://twitter.com/AndyOz2/status/974038941341896705 
It is very unlikely that any working scientist would subscribe to 'absolute' genetic determinism or fatalism based on a misunderstanding of the Central Dogma (Cobb, 2017). This type of overstatement is, however, quite typical of contrarian discourse, for example in the context of climate change (see Nerlich, 2010). In this way, merchants of epigenetics 'woo' to spread doubt about mainstream genetics in order to sell their products as well as a new 'dogma' of self-governance through epigenetics. Working epigeneticists, interviewed for a study carried out by Pickersgill, are aware of the dangers of this type of discourse. They point out that:

'People are excited about this possibility that they're not not only slaves of the genome, that they could influence by whatever magic potion the epigenome, and therefore alter and potentially undo things that have happened to their epigenome in the past. And therefore better their lives with this magic potion that we're supposed to come up at some point with! [laughs]' (Pickersgill, 2016: 106).

\section{Darwinism is dead}

In ways similar to social scientists, some advertisers have declared the death of (neo)Darwinism. One tweeter for example proclaims: 'Genetic studies are debunking evolution ${ }^{17}$.'

She refers to an article that declares:

If you have been following genetic and epigenetic studies conducted within the edifices of modern science over the past couple of decades, you likely have suspected what I am about to tell you: Mr. Darwin has already left the building, his disheveled 'Theory of Evolution' in tow ${ }^{18}$.'

However, some advertisers go further than academics; they move into the terrain of creationism and intelligent design. Marketing of epigenetic products promises to free individuals from genetic 'fatalism' and to enable customers to engage in what one might call 'the intelligent design of the self' (Nerlich, 2017). The spectre of genetic determinism is replaced here by the mirage of epigenetically enabled self-determinism, echoing some pronouncements by 'visible scientists' reviewed above. Some historians of science toy with similar ideas, as for example Michael Bess in his book Our Grandchildren Redesigned (Bess, 2015).

It should be stressed that some of the hype we found around epigenetic wellness products goes well beyond anything a social scientist would say, such as: 'AEGEA ENERGENTICS NITRO is the world's first Bio-Energy hologram for Nitric Oxide* boost [...] a quantic interface through epigenetic influence on the energetic frequencies of the human body ${ }^{19}$.'

\section{Discussion}

\footnotetext{
${ }^{17}$ Available at: https://twitter.com/MaryVMos1/status/1024806307214307328

${ }^{18}$ Enos R, 'New genetic study seriously challenges Darwin's 'Theory Of Evolution", Collective Evolution, June 4, 2018. Available at: https://www.collective-evolution.com/2018/06/04/new-genetic-study-seriouslychallenges-darwins-theory-of-evolution/

${ }^{19}$ Available at: https://twitter.com/nonewspeak/status/1073533778138607616
} 
As far as we know, social representations of epigenetics shaped by metaphors and commonplaces emerged quite independently in advertising and social science academia but in both cases were inspired by the work of 'visible scientists' who functioned as 'messengers of meaning' (Maasen \& Weingart, 2013). And yet, despite being disconnected from each other, we found some surprising similarities between metaphors used in these two normally quite distant domains of social life.

As Robert Farr said in his paper 'Common sense, science and social representations' (Farr, 1993): 'Once a scientific theory enters the public arena it acquires a life of its own. It is elaborated and developed in lay as well as in scientific circles. In the former it becomes a social representation; in the latter it remains a theory' (Farr, 1993: 194).

Here we have studied two systems of social representations of epigenetics circulating in two domains: in the advertising of alternative health products and services, and in (social science) academia. These are both 'lay circles' with regard to epigenetics, but both influenced by 'scientific circles', in particular members of such circles that popularise their science. What social representations did we find, in particular with regard to figuration, i.e. metaphors and commonplaces, and with regard to core and peripheral elements?

In some parts of academia, epigenetics is seen as providing an opportunity for overcoming the 'great divide' (a central metaphor) between the biological and the social and for building bridges between the social and the life sciences. It seems to show that this divide 'does not have to remain an eternal curse' (Meloni, 2014a: 608). Not to do so would mean 'to stay trapped in the current oscillation between uncritical importation and disdainful rejection of biological knowledge into the social field' (Meloni, 2014c: 743).

Linked to this core metaphor of (overcoming) the barrier are two supporting metaphors that breach it, namely genetic plasticity and genetic memory. In terms of associated commonplaces, this implies, at least to some extent, a rejection of the Central Dogma and a (sometimes cautious) acceptance of neo-Lamarckism and transgenerational epigenetic inheritance/memory. Only then can social scientists hope to apply biosocial thinking to reforming pedagogy, social inequalities and social justice.

In advertising the core meaning/representations of epigenetics was that of leaving behind the shackles of genetic control over the human body and mind. The supporting metaphors used here were more closely linked to older metaphors of genetic blueprints and programmes, metaphors that were contested, just like that of the 'book of life' in the social sciences. The hope was that epigenetics would replace fixed genes with flexible and malleable ones, ones that we can shape ourselves.

Both advertising and academia were influenced by early epigenetic work, such as that produced by Meaney and Szyf, which seemed to show that genes are not our destiny, and by early endorsements of the hypothesis of transgenerational epigenetic inheritance, by Jablonka, for example.

While social scientists reject genetic determinism and aim to gain better insights into bodies and society, advertisers reject determinism and aim to sell products that promise to create better bodies and selves. Although academics do not go as far as to 
subscribe to creationism and intelligent design as some alternative health proponents do, they nevertheless criticise the limitations of traditional evolutionary theory severely. And while advertisers rail against genetic fatalism, academics oppose a 'view of biology as an unchangeable form of secular destiny' (Meloni, 2014b).

Academic writers and advertisers/tweeters differ in their core metaphor use to some extent. While the more theoretical and conceptual strand of academic writing is built around erecting pseudo-barriers and pulling them down with the help of epigenetics, there is no talk about boundaries and barriers in the advertising sample, apart from the barrier posed by the skin, a barrier that is also evoked metaphorically in the social science literature through the cliché of epigenetics explaining 'how the environment gets under the skin'.

Both academics and advertisers share a metaphorical framing and reframing of the gene and genome from a so-called fixed entity to a dynamic, flexible and plastic one. Both position traditional biology as 'gene-centric' and want to replace it with a 'social' gene or genome 'reprogrammable' by epigenetics. Both hanker after 'genoplasticity'. Both speculate about being able to address social and psychological ills such as trauma brought about by child abuse, colonialism (Niewöhner \& Lock, 2018) or social injustice (Youdell, 2018).

While advertisers reject the Central Dogma and evolutionary theory to make people believe in what one may call 'the intelligent design of the self', social scientists reject these paradigms to advocate a new way of looking at the social and the biological through the lens of social responsibility and ultimately social policy. There are however critical voices warning against an over-interpretation of epigenetics in this context (Wastell \& White, 2017; Robison, 2018).

Both discourses promote particular social representations of epigenetics through the use of metaphors and commonplaces. These contain, however, what Max Black called half-truths or misunderstandings, as they draw on strands of epigenetic research which are controversial and not representative of this field (Dubois et al., 2018: 92), and which clash with mainstream scientific representations of epigenetics (Gorski, 2013; Greally, 2018). We shall only point to the most glaring ones. This might point to obstacles that have to be overcome in collaborations between natural and social scientists using epigenetics as an 'interdiscipline'.

Epigenetics does not show that genomics is in crisis (see Coyne, 2012). As Deichmann has pointed out: 'Research labelled epigenetics has not replaced the centrality of genomic information' (Deichmann, 2016: 249). The Central Dogma is not dead, unless one misunderstands it (see Cobb, 2017). Lamarckism is not alive, unless one misunderstands it (see Robison, 2018; Cobb, 2018; Haig, 2018). Epigenetic memory exists, but so far there is no proof that in humans it extends beyond a couple of generations; and it does not apply to social and cultural 'experiences' (Mitchell, 2018).

Promotional metaphors used by advertisers generally mislead the public. It should be stressed, however, that promotional metaphors and commonplaces not tied to solid scientific evidence, used by some natural and social scientists, might also 'mislead the 
public', and, might also 'create problems for the scientists themselves' (see Nelkin, 1994: 25).

Metaphors and hyperboles in advertising have attracted criticism from both natural scientists (Maderspacher, 2010; Henikoff, 2018) and social scientists (Meloni, 2014b). However, social scientists seem not yet aware of the fact that some of their rhetoric comes quite close to that of advertisers. Hence there is a danger that once they start to collaborate with social scientists, epigeneticists' mistrust of metaphors and commonplaces used by advertisers (Mitchell, 2019) might spill over into distrust of social scientists using similar notions.

\section{Conclusion}

What do these findings mean for interdisciplinary collaboration?_In 2010 there were speculations that '[e]pigenetics could serve as a bridge between the social sciences and the biological sciences, allowing a truly integrated understanding of human health and behaviour' (McGowan \& Szyf, 2010: 71). Much has happened in epigenetics and social science since then. On the one hand some social scientists have promoted a new biosocial programme of research, based on relatively simplistic and in some cases contested notions of epigenetics; on the other hand, working epigeneticists have shown just how complicated and complex epigenetics is. There is thus a potential conflict brewing between mainstream life scientists and their rather cautious approach to epigenetics (with some exceptions), the social sciences and its perhaps less restrained approach, and popular culture perceptions based on overselling epigenetics.

Pickersgill, a social scientist, sensed the emergence of this conflict when he interviewed epigenetic scientists who expressed concern about the communication of epigenetics to non-scientists. In particular, the controversial notion of transgenerational inheritance was sometimes configured as a kind of 'alien science' (Collins, 1999) - that is, knowledge often deemed deficient in facticity to subject specialists, but highly compelling to those adjacent to or acquainted with the field' (Pickersgill, 2016: 198). This situation poses practical and ethical problems for collaboration and for science communication. As one epigeneticist noted: 'If you were to ask me, what the ethical problems with epigenetics are, I'd say, using rubbish data to influence people's behaviour through pseudo-science. That's would I would say is the big ethical risk of epigenetics' (Pickersgill, 2016: 195).

We argue that this applies just as well to academia as to advertising. Interdisciplinary work should not be based on extrapolation, exaggeration, speculation, ostentation or, indeed, hype (Dubois et al., 2018: 92). Social scientists set out to dismantle 'barriers' and to build 'bridges' between the biological and the social. But do the bridges they built work? Do they encourage collaboration? Only the future can tell. This article tried to point out some obstacles waiting on or under the proposed bridges, obstacles we need to think about before extolling the virtues of collaboration.

One of the authors was recently involved in a bioethics and epigenetics discussion which revealed strong reservations among working epigeneticists about using epigenetics to advance new agendas in social science and policy, especially with regard to the issue of transgenerational epigenetic inheritance which, they felt, is not supported by convincing evidence. Applications of epigenetic concepts in the social realm were deemed by some to 
be 'premature', or even distracting from burning social issues, such as inequality, which should be tackled anyway. Referring to the use and abuse of epigenetic concepts outside of the natural sciences, one participant argued that despite controversies surrounding epigenetics, especially transgenerational inheritance, many edifices have been built on iffy foundations, and, despite this, new bricks continue to be added on top of older bricks.

This means that social scientists have to be careful choosing the bricks they use, especially ones shaped by metaphors and commonplaces, when building theories, practices and collaborations.

\section{Funding}

Catherine A. Ennis is supported by the Sunny Hill BC Leadership Chair in Child Development and a Canadian Institutes of Health Research Team Grant on Developmental Origins of Health and Disease - Implications for Men, Women, Boys and Girls - both awarded to Dr. Michael S. Kobor, University of British Columbia and BC Children's Hospital Research Institute.

\section{References}

Abric JC (2001) A structural approach to social representations. In: Deaux K, Philogène G (eds) Representations of the Social: Bridging Theoretical Traditions. Malden: Blackwell Publishing, 42-47.

Ball P (2018) Carl Zimmer: 'We shouldn't look to our genes for a quick way to make life better'. The Guardian, 11 August.

Baedke J (2018) Above the Gene, Beyond Biology: Towards a Philosophy of Epigenetics. Pittsburgh: University of Pittsburgh Press.

BBC (2018) The Big Idea: Epigenetics. In: BBC World Service. Available at: https://www.bbc.co.uk/programmes/p066wkwv (accessed 4 March 2019).

Beale GH (2019) August Weismann. In: Encyclopaedia Britannica. Available at: https://www.britannica.com/biography/August-Weismann (accessed 4 March 2019).

Bess M (2015) Our Grandchildren Redesigned: Life in the Bioengineered Society of the Near Future. Boston: Beacon Press.

Black M (1955) Metaphor. Proceedings of the Aristotelian Society 55(1): 273-294.

Blakeslee S (2003) A pregnant mother's diet may turn the genes around. The New York Times, 7 October.

Bohacek J, Engmann O, Germain PL, Schelbert S, Mansuy IM (2018) Transgenerational epigenetic inheritance: From biology to society - Summary Latsis Symposium Aug 28-30, 2017, Zürich, Switzerland. Environmental Epigenetics 4(2): 1-6.

Bonduriansky R, Day T (2018) Extended Heredity: A New Understanding of Inheritance and Evolution. Princeton: Princeton University Press. 
Bucchi M (1998) Science and the Media: Alternative Routes to Scientific Communications. Abingdon: Routledge.

Cailloce L (2019) Edith Heard ou la révolution épigénétique. In: CNRS. Le Journal. Available at https://lejournal.cnrs.fr/articles/edith-heard-ou-la-revolution-epigenetique (accessed 8 May 2019).

Callard F, Fitzgerald D (2015) Rethinking Interdisciplinarity Across the Social Sciences and Neurosciences. London: Palgrave Pivot.

Cao-Lei L et al. (2014) DNA methylation signatures triggered by prenatal maternal stress exposure to a natural disaster: Project Ice Storm. PLoS One 9(9): e107653.

Chung E et al. (2016) Social epigenetics: A science of social sciences? The Sociological Review Monographs 64(1): 168-185.

Cobb M (2017) 60 years ago, Francis Crick changed the logic of biology. PLoS Biology 15(9): e2003243.

Cobb M (2018) Review: The Tangled Tree and Lamarck's Revenge are genetic misfits. The New Scientist, 24 October.

Collins HM (1999) Tantalus and the aliens: Publications, audiences and the search for gravitational waves. Social Studies of Science 29(2): 163-197.

Coppedge DF (2019) Epigenetics in the news. In: Creation Evolution Headlines. Available at: https://crev.info/2019/01/epigenetics-in-the-news/ (accessed 18 March 2019).

Coyne J (2012) Another philosopher proclaims a non-existent 'crisis' in evolutionary biology. In: Why Evolution is True. Available at: https://whyevolutionistrue.wordpress.com/2012/09/07/another-philosopher-proclaims-anonexistent-crisis-in-evolutionary-biology/ (accessed 4 March 2019).

Deichmann U (2016) Epigenetics: The origins and evolution of a fashionable topic. Developmental Biology 416(1): 249-254.

Deichmann U (2017) Biology and political ideologies: On the futility of scientific justification for political values, now and in the past. Metascience 26(2): 289-292.

Dickins TE, Dickins BJA (2008) Mother nature's tolerant ways: Why non-genetic inheritance has nothing to do with evolution. New Ideas in Psychology 26(1): 41-54.

Dubois M (2017) Epigenetics and the new politics of heredity. European Journal of Sociology / Archives Européennes de Sociologie 58(3): 596-603.

Dubois $M$ et al. (2018) De la génétique à l'épigénétique : une révolution 'post-génomique' à I'usage des sociologues. Revue française de la sociologie 59(1): 71-98.

Dupras C (2017) Rapprochement des pôles nature et culture par la recherche en épigénétique: dissection d'un bouleversement épistémologique attendu. Les ateliers de l'éthique 12(2/3): 120-145. 
Dupré J (2010) The polygenomic organism. The Sociological Review 58(1 supplement): 1931.

Dupré J (2012) Evolutionary theory's welcome crisis. In: Project Syndicate. Available at: https://www.project-syndicate.org/commentary/evolutionary-theory-s-welcome-crisis-byjohn-dupre?barrier=accesspaylog (accessed 4 March).

Economic and Social Research Council (n.d.) Biosocial research. Available at: https://esrc.ukri.org/research/our-research/biosocial-research/ (accessed 4 March 2019).

Elsevier (n.d.) Scopus. In: Elsevier Available at: https://www.elsevier.com/solutions/scopus (accessed 4 March 2019).

Farr RM (1993) Common sense, science and social representations. Public Understanding of Science 2(3): 189-204.

Fitzgerald D, Rose N, Singh I (2016) Revitalising sociology: Urban life and mental illness between history and the present. British Journal of Sociology 67(1): 138-160.

Gieryn TF (1983) Boundary-work and the demarcation of science from non-science: Strains and interests in professional ideologies of scientists. American Sociological Review 48(6): 781-795.

Goodell R (1977) The Visible Scientists. Boston: Little Brown.

Gorski D (2013) Epigenetics. You keep using that word. I do not think it means what you think it means. In: ScienceBlogs. Available at: https://scienceblogs.com/insolence/2013/02/11/epigenetics-you-keep-using-that-word-ido-not-think-it-means-what-you-think-it-means (accessed 4 May 2019).

Greally JM (2015a) Over-interpreted epigenetics study of the week. In: EpgntEinstein. Available at: http://epgntxeinstein.tumblr.com/post/127416455028/over-interpretedepigenetics-study-of-the-week (accessed 4 March 2019).

Greally JM (2015b) Epigenetics and the Gartner hype cycle. In: EpgntxEinstein. Available at: http://epgntxeinstein.tumblr.com/ (accessed 4 March 2019).

Greally JM (2018) A user's guide to the ambiguous word 'epigenetics'. Nature Reviews Molecular Cell Biology 19: 207-208.

Greally JM, Drake AJ (2017) The current state of epigenetic research in humans: Promise and reality. JAMA Pediatrics 171(2): 103-104.

Griffiths P, Stotz K (2013) Genetics and Philosophy. An Introduction. Cambridge, UK: Cambridge University.

Grossniklaus U et al. (2013) Transgenerational epigenetic inheritance: How important is it? Nature Reviews Genetics 14: 228-235.

Häfner SJ, Lund AH (2016) Great expectations - Epigenetics and the meandering path from bench to bedside. Biomedical Journal 39(3): 166-176. 
Haig D (2007) Weismann Rules! OK? Epigenetics and Lamarckian temptation. Biology \& Philosophy 22(3): 415-428.

Haig D (2012) Commentary: The epidemiology of epigenetics. International Journal of Epidemiology 41(1): 13-16.

Haig D (2018) The ghost in the machine. The FASEB Journal 32(2): 540-542.

Heard E, Martienssen RA (2014) Transgenerational epigenetic inheritance: Myths and mechanisms. Cell 157(1): 95-109.

Heijmans T et al. (2008) Persistent epigenetic differences associated with prenatal exposure to famine in humans. Proceedings of the National Academy of Sciences 105(44): 17046-17049.

Henikoff S (2018) Darwin meets Waddington. Current Biology 28(12): PR682-R684.

Henikoff S, Greally JM (2016) Epigenetics, cellular memory and gene regulation. Current Biology 26(14): R644-R648.

Horsthemke B (2018) A critical view on transgenerational epigenetic inheritance in humans. Nature Communications 9(1): 1-4.

Ignatow G, Mihalcea R (2017) An Introduction to Text Mining: Research Design, Data Collection, and Analysis. Thousand Oaks, CA: SAGE.

Ingold T (2013) Prospect. Death of a paradigm. In: Ingold T, Pálsson G (eds) Biosocial Becomings: Integrating Social and Biological Anthropology. Cambridge: Cambridge University Press, 1-21.

Ingold T, Pálsson G (eds) (2013) Biosocial Becomings: Integrating Social and Biological Anthropology. Cambridge: Cambridge University Press.

Jablonka E (2016) Cultural epigenetics. The Sociological Review 64(1 supplement): 42-60.

Jablonka E, Lamb MJ (1995) Epigenetic Inheritance and Evolution: The Lamarckian Case. Oxford: Oxford University Press.

Jaspal R, Nerlich B (2017) Polarised press reporting about HIV prevention: Social representations of pre-exposure prophylaxis in the UK press. Health 21(5): 478-497.

Jirtle RL, Skinner MK (2007) Environmental epigenomics and disease susceptibility. Nature Reviews Genetics 8(4): 253-262.

Kaufman SB (2019) There is no nature-nurture war. In: Scientific American: Beautiful Minds. Available at: https://blogs.scientificamerican.com/beautiful-minds/there-is-no-naturenurture-war/ (accessed 4 March 2019).

Kazachenka A et al. (2018) Identification, characterization, and heritability of murine metastable epialleles: Implications for Non-genetic Inheritance. Cell 175(5): 1259-1271.

Keller EF (2014) From gene action to reactive genomes. The Journal of Physiology 592(11): 2423-2429. 
Lakoff G, Johnson M (1980) Metaphors We Live By. Chicago: Chicago University Press.

Lamont M, Molnár V (2002) The study of boundaries in the social sciences. Annual Review of Sociology 28: 167-195.

Landecker H, Panofsky A (2013) From social structure to gene regulation, and back: A critical introduction to environmental epigenetics for sociology. Annual Review of Sociology 39(1): 333-357.

Lappé M (2016) Epigenetics, media coverage, and parent responsibilities in the postgenomic era. Current Genetic Medicine Reports 4(3): 92-97.

Lappé M, Landecker H (2015) How the genome got a life span. New Genetics and Society 34(2): 152-176.

Latzko-Toth G, Bonneau C, Millette M (2017) Small data, thick data: Thickening strategies for trace-based social media research. In: Sloan L, Quan-Haase A (eds) The SAGE Handbook of Social Media Research Methods. London: Sage.

Learn.Genetics (n.d.) Lick Your Rats. In: Learn. Genetics: Genetic Science Learning Centre. Available at: https://learn.genetics.utah.edu/content/epigenetics/rats/? hstc $=170503551.36 \mathrm{dbfe} 7372$ d5c467a1b3114e4d6e0ad3.1472256000054.1472256000056.1472256000057.2\& $\mathrm{hssc}=1$ 70503551.1.1472256000057\& hsfp=1773666937 (accessed 4 March 2019).

Lloyd S, Müller R (2018) Situating the biosocial: Empirical engagements with environmental epigenetics from the lab to the clinic. BioSocieties 13(4): 675-680.

Lock M (2013) The epigenome and nature/nurture reunification: A challenge for anthropology. Medical Anthropology 32(4): 291-308.

Lock M (2018a) Epigenetics. In: Gibbon S, Prainsack B, Hilgartner S, Lamoreaux J (eds) Routledge Handbook of Genomics, Health and Society. London: Routledge.

Lock M (2018b) Mutable environments and permeable human bodies. Journal of the Royal Anthropological Institute 24(3): 449-474.

Lock M, Nguyen VK (2010) An Anthropology of Biomedicine. Oxford: Wiley-Blackwell.

López J (2003) Society and Its Metaphors: Language, Social Theory and Social Structure. New York and London: Continuum.

Maasen S, Weingart P (2013) Metaphor and the Dynamics of Knowledge. London: Routledge.

Maderspacher F (2010) Lysenko rising. Current Biology 20(19): R835-R837.

Marwick A (2014) Ethnographic and qualitative research on Twitter. In: Weller K et al. (eds) Twitter and Society. New York: Peter Lang, 109-122.

McGill (n.d.) Breaking the bonds of genetic destiny. In: McGill Available at: https://www.mcgill.ca/about/history/features/epigenetics (accessed 8 May 2019). 
McGowan PO, Szyf M (2010) The epigenetics of social adversity in early life: Implications for mental health outcomes. Neurobiology of Disease 39(1): 66-72.

Meaney MJ (2001a) Maternal care, gene expression, and the transmission of individual differences in stress reactivity across generations. Annual Review of Neuroscience 24: 1161-1192.

Meaney MJ (2001b) Nature, nurture and the disunity of knowledge. Annals of the New York Academy of Sciences 935: 50-61.

Meloni M (2014a) How biology became social, and what it means for social theory. The Sociological Review 62(3): 593-614.

Meloni M (2014b) The social brain meets the reactive genome: Neuroscience, epigenetics and the new social biology. Frontiers in Human Neuroscience 8: 309.

Meloni M (2014c) Biology without biologism: Social theory in a postgenomic age. Sociology 48(4): 731-746.

Meloni M (2016) From boundary-work to boundary object: How biology left and re-entered the social sciences. The Sociological Review 64(1 supplement): 61-78.

Meloni M (2018a) After and beyond the genome: Taking postgenomics seriously. In: Somatosphere. Available at: http://somatosphere.net/2018/06/after-and-beyond-thegenome.html (accessed 4 March 2019).

Meloni M (2018b) A postgenomic body: Histories, genealogy, politics. Body \& Society 24(3): 3-38.

Meloni M, Cromby J, Fitzgerald D, Lloyd S (eds) (2018a) The Palgrave Handbook of Biology and Society. London: Palgrave Macmillan.

Meloni M, Cromby J, Fitzgerald D, Lloyd S (eds) (2018b) Introducing the new biosocial landscape. In: Meloni M, Cromby J, Fitzgerald D, Lloyd S (eds) The Palgrave Handbook of Biology and Society. London: Palgrave Macmillan, 1-22.

Meloni M, Testa G (2014) Scrutinizing the epigenetics revolution. BioSocieties 9(4): 431456.

Meloni M, Williams S, Martin P (eds) (2016) Biosocial Matters: Rethinking the SociologyBiology Relations in the Twenty-First Century. Oxford: Wiley-Blackwell.

Mercola J (2012) Falling for this myth could give you cancer. In. Mercola: Take Control of Your Health. Available at: https://articles.mercola.com/sites/articles/archive/2012/04/11/epigenetic-vsdeterminism.aspx (accessed 4 March 2019).

Mitchell K (2018) Grandma's trauma - A critical appraisal of the evidence for transgenerational inheritance in human. In: Wiring the Brain. Available at: http://www.wiringthebrain.com/2018/05/grandmas-trauma-critical-appraisal-of.html (accessed 4 March). 
Mitchell K (2019) Epigenetics: What impact does it have on our psychology? In: The Conversation. Available at: https://theconversation.com/epigenetics-what-impact-does-ithave-on-our-psychology-109516 (accessed 4 March 2019).

Moran L (2007) Basic concepts: The Central Dogma of Molecular Biology. In: Sandwalk. Available at: https://sandwalk.blogspot.com/2007/01/central-dogma-of-molecularbiology.html (accessed 4 March 2019).

Morange $M$ (2002) The relations between genetics and epigenetics: $A$ historical point of view. Annals of the New York Academy of Sciences 981: 50-60.

Morange M (2008) What history tells us XIII: Fifty years of the central dogma. Journal of Biosciences 33(2): 171-175.

Moscovici S (1981) On social representations. In: Forgas JP (ed.) Social Cognition: Perspectives on Everyday Understanding. London: Academic Press, 181-209.

Moscovici S (1988) Notes towards a description of social representations. European Journal of Social Psychology 18(3): 211-250.

Moscovici S, Hewstone M (1983) Social representations and social explanations: From the 'naïve' to the 'amateur' scientist. In: Hewstone M (ed.) Attribution Theory: Social and Functional Extensions. Oxford: Basil Blackwell, 98-125.

Nelkin D (1994) Promotional metaphors and their popular appeal. Public Understanding of Science 3(1): 25-31.

Nerlich B (2010) 'Climategate': Paradoxical metaphors and political paralysis. Environmental Values 19(4): 419-442.

Nerlich B (2016) When epigenetics gets under the skin. In: Making Science Public. Available at: https://blogs.nottingham.ac.uk/makingsciencepublic/2016/08/15/epigenetics-getsskin/ (accessed 4 March 2019).

Nerlich B (2017) Epigenetics, hype and woo. In: Making Science Public. Available at: http://blogs.nottingham.ac.uk/makingsciencepublic/2017/03/31/epigenetic-hype-woo/ (accessed 12 March 2019)

Nerlich B, Stelmach A (2018). Epigenetics: Grappling with definitions. In: Making Science Public. Available at: http://blogs.nottingham.ac.uk/makingsciencepublic/2018/08/31/epigenetics-grapplingwith-definitions/ (accessed 4 March 2019).

Niewöhner J (2011) Epigenetics: Embedded bodies and the molecularisation of biography and milieu. BioSocieties 6(3): 279-298.

Niewöhner J, Lock M (2018) Situating local biologies: Anthropological perspectives on environment/human entanglements. BioSocieties 13(4): 681-697.

Noble D (2018) Central dogma or central debate? Physiology 33(4): 246-249. 
Pembrey ME (2002) Time to take epigenetic inheritance seriously. European Journal of Human Genetics 10(11): 669-671.

Pickersgill M (2016) Epistemic modesty, ostentatiousness and the uncertainties of epigenetics: On the knowledge machinery of (social) science. The Sociological Review Monographs 64(1): 186-202.

Pickersgill M (2019) Epigenetics, education, and the plastic body: Changing concepts and new engagements. Research in Education, 0034523719867102.

Pickersgill $M$ et al. (2013) Mapping the new molecular landscape: social dimensions of epigenetics. New Genetics and Society 32(4): 429-447.

Robison SK (2018) Epigenetics and Public Policy: The Tangled Web of Science and Politics. Santa Barbara: ABC-CLIO, LLC.

Russel Sage Foundation (n.d.) Integrating biology and social science knowledge (BioSS). Available at: https://www.russellsage.org/research/funding/bioss (accessed 4 March 2019).

Schuol S (2017) Epigenetics and genetic determinism (in popular science). In: Heil R et al. (eds) Epigenetics. Wiesbaden: Springer, 41-54.

Scott-Phillips T et al. (2011) Evolutionary theory and the ultimate-proximate distinction in the human behavioral sciences. Perspectives on Psychological Science 6(1): 38-47.

Smith GD (2012) Epigenetics for the masses: More than Audrey Hepburn and yellow mice? International Journal of Epidemiology 41(1): 303-308.

Snow CP (2001[1959]) The Two Cultures. London: Cambridge University Press.

Spector T (2012) Identically Different: Why You Can Change Your Genes. London: Weidenfeld \& Nicolson.

Staropoli N (2017) Our microbiome: Separating hype from health. In: Making Science Public. Available at: http://blogs.nottingham.ac.uk/makingsciencepublic/2017/05/05/microbiome-separatinghype-health/ (accessed 4 March 2019).

Stelmach A, Nerlich B (2015) Metaphors in search of a target: The curious case of epigenetics. New Genetics and Society 34(2): 196-218.

Szyf M (2011) DNA methylation, the early-life social environment and behavioral disorders. Journal of Neurodevelopmental Disorders 3(3): 238-249.

Szyf M (2015) Nongenetic inheritance and transgenerational epigenetics. Trends in Molecular Medicine 21(2): 134-144.

Szyf M (2016) Epigenetics - Our bodies' way to change the destiny written in our DNA. In: YouTube. Available at: https://www.youtube.com/watch?v=SrqmuYvk3iQ (accessed 4 March 2019). 
Szyf M (2018) Healthtech O2O Summit - Dr. Moshe Szyf, HKG Epitherapeutics. In: YouTube. Available at: https://www.youtube.com/watch?v=6U9laLyreZg (accessed 8 May 2019).

Tolwinski K (2013) A new genetics or an epiphenomenon? Variations in the discourse of epigenetics researchers. New Genetics and Society 32(4): 366-384.

Van de Vijver G, Van Speybroeck L, De Waele D (2002) Epigenetics: A challenge for genetics, evolution, and development? Annals of the New York Academy of Sciences 981: $1-6$.

Van Dijck J (1998) Imagenation: Popular Images of Genetics. New York: New York University Press.

Wastell D, White S (2017) Blinded by Science: The Social Implications of Epigenetics and Neuroscience. Bristol: Bristol University Press.

Waterland RA, Jirtle RL (2003) Transposable elements: Targets for early nutritional effects on epigenetic gene regulation. Molecular and Cellular Biology 23(15): 5293-5300.

Watters E (2006) DNA is not destiny: The new science of epigenetics. Discover Magazine, 22 November, 32-37.

Weaver ICG et al. (2004) Epigenetic programming by maternal behaviour. Nature Neuroscience 7(8): 847-854.

Yeager A (2019) Classic mechanism of epigenetic inheritance is rare, not the rule. In: The Scientist. Available at: https://www.the-scientist.com/notebook/classic-mechanism-ofepigenetic-inheritance-is-rare--not-the-rule-

65511?utm content $=87099062$ \&utm medium $=$ social\&utm source=twitter\&hss channel= tw-18198832 (accessed 14 March 2019).

Yearley S (2012) The epigenetic revolution. In: YouTube. Available at: https://www.youtube.com/watch?V=A4YkWBcU G0 (accessed 4 March).

Yehuda R et al. (2016) Holocaust exposure induced intergenerational effects on FKBP5 methylation. Biological Psychiatry 80(5): 372-380.

Yehuda R, Lehrner A, Bierer LM (2018) The public reception of putative epigenetic mechanisms in the transgenerational effects of trauma. Environmental Epigenetics 4(2): dvy018.

Youdell R (2016) A biosocial education future? Research in Education 96(1): 52-61.

Youdell R (2017) Bioscience and the sociology of education: The case for biosocial education. British Journal of Sociology of Education 38(8): 1273-1287.

Youdell R (2018) Genetics, epigenetics and social justice in education: Learning as a complex biosocial phenomenon. In: Meloni M, Cromby J, Fitzgerald D, Lloyd S (eds) The Palgrave Handbook of Biology and Society. London: Palgrave Macmillan UK, 295-315.

Youdell D, Harwood V, Lindley MR (2018) Biological sciences, social sciences and the languages of stress. Discourse: Studies in the Cultural Politics of Education 39(2): 219-241. 
Youdell R, Lindley MR (2018) Biosocial Education: The Social and Biological Entanglements of Learning. London: Routledge.

Zwart H (2016) Genetic determinism. In: Ten Have H (eds) Encyclopedia of Global Bioethics. Cham: Springer. 